\title{
IZOBRAŽEVALNA ZAPUŠČINA DANILA DOLCIJA
}

Dr. Nives

Ličen,

Filozofska

fakulteta

Univerze v

Ljubljani

\section{Danilo Dolci-izobraževalec, pesnik, sociokulturni animator, družbeni upornik}

\section{POVZETEK}

Dolci je bil eden od avtorjev, ki so oblikovali tok pedagoške in andragoške prakse ter teorije v prejšnjem stoletju. Ko se je naselil na Siciliji in je začel razmišljati, kako bi ljudem, ki so ostali na robu industrijskega razvoja, pomagal, je ugotovil, da lahko projekte uresniči le tako, da jih pripravlja skupaj z ljudmi po načelu subsidiarnosti. Razvojni projekti morajo začeti svojo pot znotraj skupine in so prežeti z veliko mero neformalnega in priložnostnega učenja. Zaradi takšnih potreb je oblikoval dialoške skupine, v katerih so se ljudje pogovarjali, razvijali razumevanje in kot skupina pripravili razvojne projekte, ki so premoščli individualizem in nezmožnost, da bi razvijali skupne interese. V desetletjih razvoja so iz dialoških skupin zrasle mnoge novosti, npr. vzpostavili so skrbstveno službo za otroke, ki so bili prepuščeni ulici, lotili so se razvojnih projektov za oblikovanje zaposlitve, za namakanje polj, za boj proti mafiji, ustanovili so eksperimentalno šolo v Mirtu...

Vse to je postajalo zanimivo za svet, Dolcija so vabili predavat na tuje univerze, saj so ugotovili, da njegovo delo ni omejeno le na Sicilijo, marveč prinaša zanimiv model učenja in novo izobraževalno paradigmo, prenosljivo tudi v druga okolja.

Ključne besede: Danilo Dolci, neformalno učenje, dialoške skupine, eksperimentalna šola

$\mathrm{L}$ kot okroglo obletnico, dotikajočo se Kosovelovega in Kocbekovega življenja. Dvema mislecema in poetoma, ki sta se borila $\mathrm{z}$ besedo in družbeno akcijo za enakopravnost ljudi, bi lahko pridružili še tretjega, prav tako poeta in misleca, ki je bil deloma slovenskega rodu in je mogoče po svoji slovenski materi pridobil nekaj slovanskega utopizma. Danilo Dolci bi imel osemdeset let, tako kot Kosovel je bil rojen y Sežani in se boril proti revščini sivi starki za vasjo, ki ljudem onemogoča dostojno življenje; želel je biti raketa, ki opozarja na polucijo uma in intelektualno kloniranje. Huxley ga je imenoval svetnik 20. stoletja, Fromm apostol nenasilja. Kdo je bil Danilo Dolci?

$\mathrm{V}$ prispevku s pomočjo komparativne in biografske metode poskušam odgovoriti na vprašanja, ali je delo Danila Dolcija aktualno tudi za slovenski prostor v času tranzicije in globalizacije, ali njegovo delo vsebuje sporočilo tudi za čas 21 . stoletja. 


\section{BIOGRAFIJA DANILA DOLCIJA}

Danilo Dolci je bil rojen v Sežani 28. junija 1924. Njegova mati je bila Slovenka, oče Italijan. Njegovi prvi spomini sežejo na Kras, zapisal je, da se spominja vonja in občutka hoje po borovih iglicah. Drugi so o njegovem otroštvu zapisali, da sta starša uporabljala telesno kazen kot vzgojno sredstvo (Mangione, Welch, 2004). Iz njegove biografije lahko sklepamo, da je klofute zelo težko doživljal (Spagnoletti, 1977).

Mati je igrala klavir, tete so pele, stari oče je igral violončelo. Otrok je poslušal pesem in

Dolci je kot sredstvo upora uporabljal nenasilje. potem moral spat. Strah ga je bilo teme. Jokal je. Njegov jok so prekinili z nekaj udarci (Spagnoletti, 1977, str. 13). Dolci se spominja, kako je na podstrešju odkril Miklavževa oblačila. Ko je mami pokazal svoje odkritje, ga je našeškala, ker je stikal po podstrešju. Spominja se tudi, kako je revnemu dečku podaril svojo novo mornarsko kapo - saj so ga učili, da mora biti dober - in je bil tepen, namesto da bi njegovo dobroto občudovali. Spominja se tudi vrtca. Po kosilu so morali dati roke na mizo, glavo položiti na roke in spati. Nadzorovala jih je nuna, ki je sedela $v$ kotu in z dolgo palico udarila vsakogar, ki se je premaknil ali šepetal. Dolci je zasovražil nasilje in to je nosil s sabo vse svoje življenje. Tako kot je Freire v otroštvu okusil lakoto in je zaradi tega izkustva vse življenje posvetil boju proti revščini, je tudi Dolci vse življenje gojil nenasilje in upor z nenasiljem.

Mladost je preživel v severni Italiji. Z družino so se selili, kot je država selila njegovega očeta po različnih železniških postajah. Oče je želel, da bi se izučil za geometra, toda Danilo se je vpisal na Liceo Artistico di Brera in nato študiral arhitekturo $v$ Rimu in Milanu. Leta 1940 je bil njegov oče premeščen na železniško postajo $v$ Trappeto na Siciliji in pri njem je preživel poletne počitnice. Sicilija ga je očarala. V Segesti je opazoval grške ruševine, zanimali so ga dorski templji. Poleg arhitekture so ga zanimali tudi ljudje in zaradi teh je kasneje sklenil ostati na Siciliji.

Mladostna leta so prinesla srečanje $z$ vojno. Danilo je zapisal v svojih spisih, da v tistih časih sicer še ni slišal za ugovor vesti, toda v sebi je čutil, da je zelo narobe, če človek ubija človeka. Svoje nestrinjanje je prelil $v$ trganje fašističnih plakatov, zaradi česar je bil prvič zaprt. Zaprla ga je fašistična oblast.

Po drugi svetovni vojni, leta 1948 , se je v Milanu srečal $\mathrm{z}$ duhovnikom don Zenom Saltinijem, ki se je boril za najrevnejše ljudi. Nanj je to naredilo velik vtis, opustil je študij arhitekture, »slekel intelektualizem«, kot je sam rekel, in se pridružil don Zenu, ki je vodil zavetišče za vojne sirote. Toda oblast jima ni bila naklonjena. Krščanska demokracija je obtožila don Zena, da je komunist, nekateri so ga imenovali »nori duhovnik«, obe sirotišnici so ukinili in otroke preselili v

Začel je delovati kot sociokulturni animator in izobraževalec, izhajajoč iz trdnega prepričanja o nenasilju, ki lahko premaga družbeno razlikovanje in krivičnost. Deloval je v okolju, kjer ni bilo cest, le prah in blato. Najprej se je učil o ljudeh, pogovarjal se je z njimi. Naučili so ga več kot katerakoli knjiga, ki bi jo kdo napisal o prebivalcih Sicilije. Ljudje so bili zadržani, Dolci je bil tujec, toda sčasoma so se mu približali, mu začeli zaupati in zaupanje je bilo prvi pogoj, da so lahko pričeli $\mathrm{z}$ neformalnim izobraževanjem. Zaupanje je pomembno pri skupnih razvojnih aktivnostih, kakršne je vodil Dolci, še pomembnejše pa je pri aktivnostih, ki se nanašajo na sodobne oblike revščine, zato ne čudi, da dandanes med elementi socialnega in kulturnega kapitala izpostavljajo prav zaupanje. 
druge azile. Dolci se je odločil, da odide v najrevnejši kraj, za katerega je vedel. To je bila zahodna Sicilija. Leta 1952 se je naselil v bližino Palerma, kjer so živeli ljudje v veliki revščini, niso bili pismeni, bili so pod pritiski mafije in kar je bilo najhuje, niso imeli nobenega upanja dobiti delo. Trappeto je Dolci označil kot gnezdo revšcine in »banditov《, razbojnikov, ki so se $\mathrm{z}$ nasiljem borili proti mafiji. Revščina je pomenila, da so ljudje za 10 do 12 ur dela na dan zaslužili le 250 lir, za kar so lahko kupili dva kilograma kruha. Revščina je pomenila, da vode, v kateri so kuhali testenine, niso zlili stran, temveč jo je kakšen, še večji revež popil. Ko je zaradi lakote umrl otrok, je Dolci začel svojo prvo gladovno stavko, da bi opozoril oblast na nemogoče razmere.

Ljudje so se začeli zbirati v skupine, analizirali so, kaj je v pokrajini vrednega, kje lahko iščejo svoje vire - proces se imenuje ljudska avtoanaliza. Najprej so želeli zgraditi jez na reki Jato, da bi lahko namakali svoja izsušena polja. Dolci je želel ljudi ozavestiti, da samo z izvajanjem nasilja, kot je npr. atentat na vlak, ne bodo spremenili svojega življenja. Revščino lahko premostijo le tako, da spoznajo svoje prednosti, vrednost svoje kulture, poiščejo svoje vire za razvoj in si zastavijo jasne cilje. Dolci je želel tudi okolju pokazati, da Sicilija ni nasilna pokräjina. Če je petdeset ljudi nasilnih, še ne pomeni, da so vsi nasilni. Da bi pokazal neupravičenost posploševanja, so morali ljudje spregovoriti, povedati, da si želijo delati in da želijo prispevati $\mathrm{k}$ razvoju. Spregovorili so ljudje in njihove zgodbe.

Dolci je začel boj proti mafiji, toda nikakor ni mogel priti v stik z oblastjo, zato se je ponovno poslužil gladovne stavke, da bi opozoril na revščino ljudi, h kateri prispeva svoj delež mafijsko urejanje življenja.

Izmislil si je tudi narobe stavko, antistavko kot način nenasilnega protesta. Leta 1958 je organiziral 150 brezposelnih moških, da so po- pravili uničeno makadamsko cesto $\mathrm{v}$ Partinicu in na tak način protestirali. Izhajal je iz prepričanja, da delo ni le pravica, ampak je tudi dolžnost. Ljudje so protestirali tako, da so delali. Kot subverzivneža so ga aretirali in osem mesecev je preživel v zaporu. Tokrat ne pod fašizmom, temveč v demokraciji.

Leta 1958 je dobil Leninovo nagrado za mir. Denar je porabil za postavitev razvojno-izobraževalnega centra (Centro studi e iniciative), ki ga je ustanovil zato, ker ljudje potrebujejo instrumentarij, da bi se lahko zavzeli zase in za svoj razvoj. Brez iniciative in ciljev je protest obsojen na neuspeh. Do oblikovanja ciljev lahko pridejo ljudje skupaj, če se pogovarjajo, če jih spodbudijo v njihovi kulturi in $\mathrm{z}$ njihovim jezikom $\mathrm{k}$ razvoju. Zato so s pomočjo zdravnikov, inženirjev in sociologov, ki so pribajali iz vse Evrope, opravili raziskavo o potrebah ljudi, iz katerih naj bi izhajalo izobraževanje. Leta 1960 so predstavili rezultate analize potreb ljudi. Ugotovili so, da je 64 odstotkov ljudi nepismenih, 90 odstotkov hiš nima tekoče vode, raziskava je pokazala tudi na zaprtost $v$ kletko zastarelih prepričanj, npr, parazitolog $\mathrm{z}$ rimske univerze je ugotovil, da je 75 odstotkov otrok imelo gliste. Toda ljudje so bili prepričani, da brez glist ne morejo prebavljati, in tudi

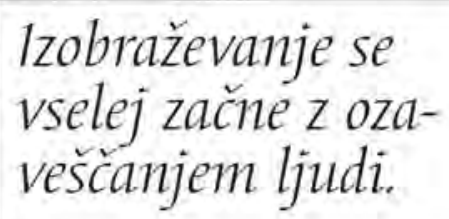
z molitvami, ki so jih imeli za to težavo, niso prosili za to, da bi gliste odpravili, temveč da bi z njimi mirno živeli. Ljudje niso spremenili svojih prepričanj, ker so živeli zaprti $v$ »kulturne kapsule«. Zdelo se jim je, da so gliste nuja. Če razumevanje prenesemo v metaforični jezik: zdelo se jim je, da so zajedalci nuja. Dolci je v svoji pesniški zbirki zapisal, da so zajedalci klopi, ki sesajo ljudem kri in se jih ljudje zelo pozno zavedo. Iz omenjenih besedil lahko razumemo, zakaj 
je bilo Dolcijevo delo za oblastnike subverzivno. Njegovo izobraževanje ni bila le karitativna pomoč, temveč osveščanje ljudi. V svojih razmišljanjih je podoben Freireju (Freire, 1971), oba sta opozorila na dialektiko med dominiranimi in dominanti - oboji so $\mathrm{v}$ sistemu, ta pa deluje, če oboji sprejemajo svoji vlogi.

Leta 1967 so ga zaprli za dve leti, ker je ljudi na oblasti poimensko obtožil skorumpiranosti in sodelovanja $\mathrm{v}$ organiziranem kriminalu. Veliko njegovih sodelavcev ga je zapustilo, ker so bili prepričani, da si s takim načinom protesta organizira propagando, obsodili so ga nepoštenosti, samovšečnosti, toda Dolci po mnenju drugih ni bil človek takega kova. Spagnoletti (1977, str. XIII) je zavrnil misel o samovšečnosti, zapisal je, da je bil Danilo Dolci nasprotnik herojstva, ker je herojstvo umeščal v preživeli romanticizem. Življenje v srednjem sloju je zapustil, da bi živel z najrevnejšimi ljudmi, zavedajoč se, da Sicilije ne more na mah spremeniti, lahko pa stori korak naprej. Med drugim se je poročil $\mathrm{z}$ žensko, ki je bila nepismena, ovdovela je s petimi otroki in Danilo je skrbel zanje. Kaplja v morje? Morje je iz kapelj! Bil je skrajno solidaren z najrevnejšimi ljudmi, njegove gladovne stavke in delovne antistavke so opozarjale oblast na probleme najrevnejših ljudi. Dokler je ljudem pomagal v revščini, je bil za oblast sprejemljiv, ko pa je oblast

Dolei je bil predlagan je bil za Nobelovo nagrado za mir, 1958. je dobil Leninovo nagrado za mir, 1970. v Stockholmu nagrado Socrates za prispevek $\mathrm{k}$ svetovnemu razvoju pedagogike in $\mathrm{v}$ Kobenhavnu nagrado Sonning za prispevek k evropski civilizaciji. V 60. letih je postal heroj kljub svojemu antiheroizmu. V Evropi in Severni Ameriki je predaval na znanih univerzah, npr. Harvardu, Standfordu, Princetonu, Yaleu, Columbii ... Prejel je dva castna doktorata: 1968. mu je univerza $\vee$ Bernu podelila častni doktorat za področje pedagoških znanosti in 1996. univerza v Bologni naziv častnega doktorja znanosti za področje edukacijskih ved. vprašal, zakaj so ljudje revni, je postal subverziven, preganjali so ga, toda njegovo delo so podprli levičarski intelektualci, njegovo delo je svet opazil.

Ob branju njegove življenjske zgodbe, ki bi bila zanimiva za psihoanalitično razčlenitev, se pokažeta dva paradoksa. Z nenasiljem se je boril proti nasilju in $\mathrm{z}$ držo antiherojstva vzgojil o sebi mit o heroju.

Danilo Dolci je bil ustvarjalec prakse, njegova raziskovanja bi danes uvrstili med akcijska raziskovanja, ki pa bi imela svojstveno poebnost, saj je ugotovitve in posplošitve izrazil prek beletristike. Na področju izobraževanja velja za človeka akcije, za izobraževalca, ki deluje in s svojim delom ustvarja novosti in refleksijo ob tem. Dolci je bil emblematičen družbeni protestnik, dokler se niso $\mathrm{v}$ njegovem okolju pojavili radikalnejši protestniki, denimo rdeče brigade, $\mathrm{ki}$ so zasenčili njegov upor proti revščini. Umrl je 30. decembra 1997. Kot vidimo, ga s Freirejem poleg podobnih biografskih drobcev, kot je denimo vloga matere pri oblikovanju odnosa do jezika, in podobnih zamisli o vzgojnoizobraževalnem delu, druži tudi letnica smrti.

\section{IZOBRAŽEVALNO-RAZVOJNI CENTRI - IZOBRAŽEVANJE KOT TEMELJ RAZVOJA}

S svojimi izhodišči o udeležbi vseh ljudi pri oblikovanju razvoja je Dolci v Italiji vzpostavil podoben koncept izobraževanja odraslih v lokalnem okolju, kot se je na angleško govorečem področju razvil s t. i. 'community education', v francoskem okolju s sociokulturno animacijo in v slovenskem prostoru $\mathrm{s}$ poskusi skupnostnega izobraževanja. Dolcijevi centri so $v$ italijanskem prostoru eden vidnejših elementov gibanja izobraževanje za razvoj skupnosti, ki se $\mathrm{v}$ sodobnem času nadaljuje v konceptu učeče se regije. Eden od 


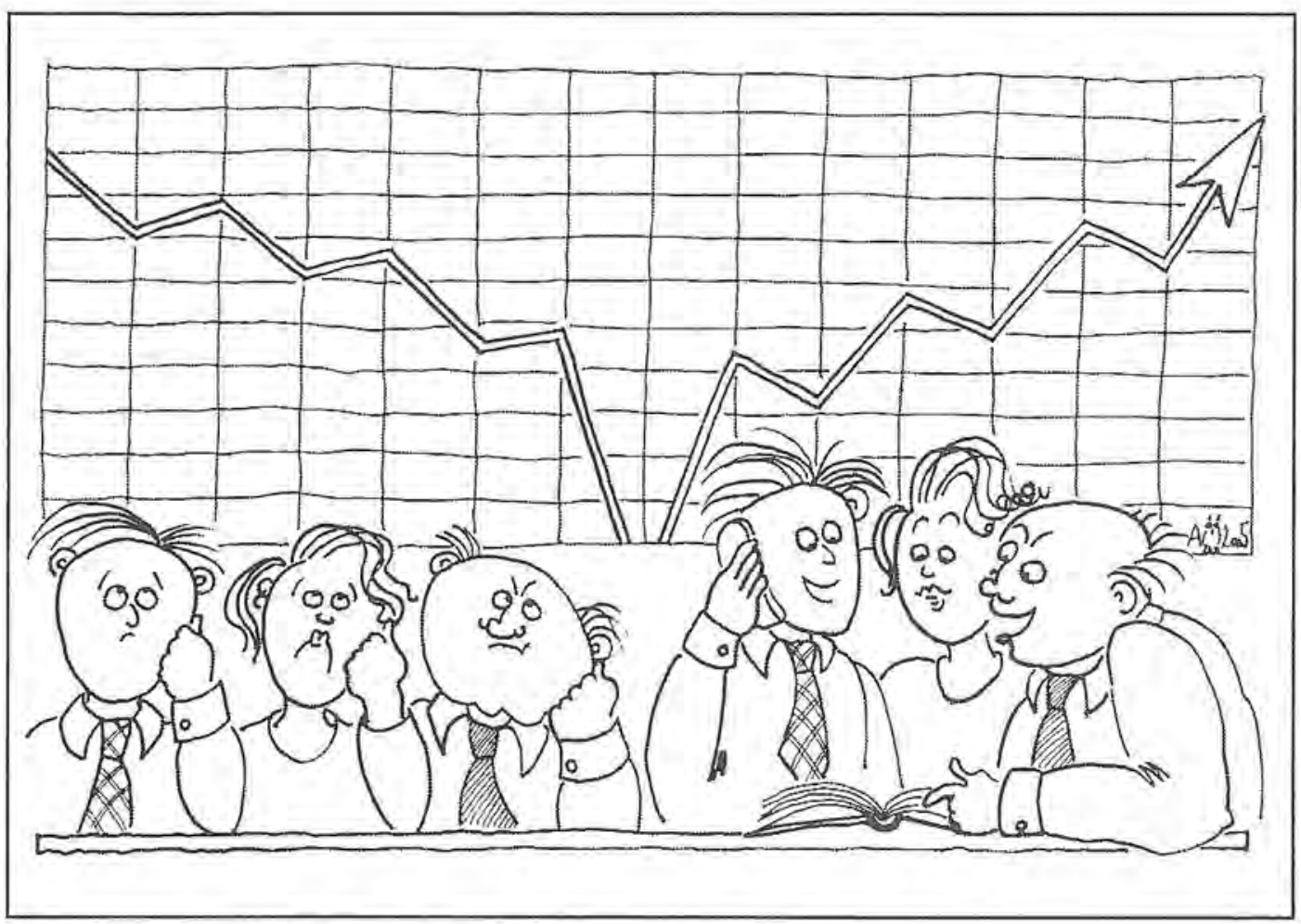

nosilcev zamisli učeče se regije v Evropi je Paolo Federighi, profesor za izobraževanje odraslih na firenški univerzi.

Dolcijev razvojno-izobraževalni center se razlikuje od drugih razvojnih centrov po tem, da ima za temeljno izhodišče razvoja okolja izóbraževanje. Ob razvojnem delu se je Dolci s svojimi sodelavci spraševal, kako ohranjati lokalno kulturo, ker ljudje potrebujejo potrditev, da je njihova kultura pomembna, da so pomembni oni sami, četudi niso podobni tistim italijanskim krajem, kjer poteka intenzivna industrializacija. Potrebovali so razvojni center, ki bo spodbujal lokalne iniciative na področju obrti, kmetijstva, ribištva, umetnosti. Iz tega se je razvila tudi njihova raziskovalna dejavnost, ki je vpeta v življenje; raziskovali so zato, da bi s pomočjo ugotovljenega nekaj spremenili, zato ne preseneča, da je raziskovanje slonelo na proučevanju življenjskih zgodb. Avtobiografska metoda, ki v petdesetih in šestdesetih letih ni bila cenjena kot raziskovalna metoda, je vplivala na razvoj metodologije raziskovanja na področju sociologije in izobraževanja. Biografsko in avtobiografsko metodo v sodobnem italijanskem izobräževanju odraslih razvijajo predvsem Demetrio s svojo skupino na milanski univerzi in na Svobodni univerzi za avtobiografijo (prim. www.lua.it).

Dolci je s svojimi evropskimi sodelavci in s finančno pomočjo iz različnih držav na Siciliji postavil več centrov. Leta 1972 je ustanovil izobraževalni center v kraju Mirto, ki je bil po arhitekturi medi-

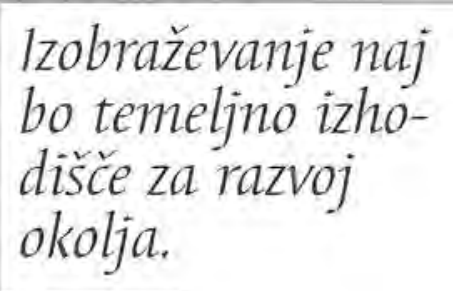
teranski, po zasnovi izobraževanja pa bolj podoben skandinavskim visokim ljudskim šolam. Takšna zasnova je nastala potem, ko so ljudi spraševali, kakšna bi bila za njih idealna šola. Dobili so odgovore, naj bo umaknjena iz mesta in naj bo v stiku z naravo, s pogledom na morje. Center je medna- 
rodno uveljavljen kot ena vidnejših inovacij na področju izobraževanja. Oblikovati je želel drugačno izobraževanje, kot ga je poznal tradicionalni šolski sistem. Dolci je

\section{Dialoške delavnice kot nova oblika zatiranja neved- nosti in strahu zaradi nevednosti.} zagovarjal dialoške delavnice (laboratori maieutici), ki naj bi prispevale $\mathrm{k}$ osvobajanju okolja različnih oblik zatiranja, nevednosti, strahu. $\checkmark$ njegovem delovanju lahko Družil se je s Habermasom in iščemo tudi vpliv Habermasovega razmišljanja, da je struktura človekove osebnosti oblikovana prek komunikacije in jo lahko zato s komunikacijo spreminjamo.

Razvili so dialoško metodo, ki izhaja iz Sokratovega modela, in jo poimenovali majevtična metoda. Niso želeli, da bi se metoda zožila na tehniko, in so poudarjali, da majevtična metoda izhaja iz
Ali lahko Dolcija stejemo za zacet- nika koncepta učeče se družbe? odnosa med osebama. Vsak član skupine je drugemu majevt, pomočnik pri oblikovanju znanja, učitelj pa je predvsem svetovalec, ki skupaj $z$ drugimi $v$ skupini pripravi učni program. Majevtično načrtovanje je nekoliko podobno načrtovanju pri projektnem pouku. Člani se zberejo na začetku tedna in se dogovorijo, kaj se bodo učili. Temeljni cilj izobraževanja se kaže $v$ učenju odkrivanja skupaj z drugimi, V oblikovanju prihodnosti v skupnosti. Razmišljanje, ki se danes nadaljuje $\mathrm{v}$ konceptu učeče se organizacije, učeče se družbe.

Problem avtoritarnosti in antiavtoritarnosti je bil vedno del njihovih seminarjev. »Jasno nam je postalo, da z uvajanjem in vztrajanjem zgolj pri t. i. permisivnih odnosih postane antiavtoritarnost ista stvar kot avtoritarnost, le smer puščice je obrnjena. Načelo spontanosti lahko razumemo kot reakcijo na antiavtoritarnost, toda ne razvija avtonomije! Ne oblikuje avtonomnih modelov! (V Spagnoletti, 1977, str. 131)

Dolci, ki je študiral t. i. avantgardne modele, je navedel izjavo nekega dekleta, ki se je dotaknilo njegovega razmišljanja: »Odrasla sem $v$ prijetnem okolju, toda odrasli okrog mene niso znali sprejeti svoje odgovornosti.« Pri dvajsetih letih, po končani glasbeni šoli, je ugotovila, da ne zna igrati violine (prav tam). Dolci je zaključil, da je pouk nujen, poučevanje je potrebno. Učenci lahko odkrivajo, če jim nekdo pomaga, je zapisal v svoji knjigi Kdo ve, če ribe jokajo.

Centri za izobraževanje in društvo, ki se je razvilo na osnovah njegovega dela, se danes imenujejo po njem: Associazione per lo sviluppo creativo Danilo Dolci. Organizirajo raziskovalne in izobraževalne dejavnosti ter razvojne projekte.

\section{NAČELA, KI SO DOLCIJA VODILA PRI DELU}

Za Dolcijevo vzgojnoizobraževalno delo veljata dve izhodišči. Prvo je predstavljeno z njegovo mislijo, ki jo je izrekel v dialogih s

Izobraževalni center Mirto je želel postati »gradbišče« novega modela izobraževanja, zato so uvajali eksperimentalne metode, npr. učitelj je raziskoval z učenci, učitelj ni poučeval o glasbi, temveč z glasbo vzgajal, literature so se učili s spodbujanjem poetičnosti, metaforičnosti v vsakem učencu.

Ker kulturo ustvarjajo vsi ljudje, ki v njej živijo, ne le profesionalci, je potrebno izobraziti vse ljudi, učili naj bi se $z$ dejavnostjo, posebno mladi ljudje, da se bodo znali učiti tudi $v$ času, ki bo sledil šolanju. Četudi ni uporabil besedne zveze vseživljenjsko učenje, lahko iz dela razberemo, da so v izobraževalnih centrih vzpostavljali osnovo za vseživljenjsko učenje prebivalcev Sicilije. 
Spagnolettijem, da edukacija postane revolucionarna, ko pomaga odkriti, da je človek materija, ki se zaveda samega sebe in brez tega ne obstaja. Zavedanje o sebi se ne razvije brez lastnega odkrivanja in brez stimulativne podpore drugih. Človekovo zavedanje se oblikuje s procesi individualizacije, samooblikovanja in socializacije, ko človeka oblikuje okolje. Prvo načelo lahko strnemo: posameznik ima aktivno vlogo pri oblikovanju samega sebe in svojega znanja.

Drugo načelo je endogeni razvoj, ko vsi prebivalci nekega okolja sodelujejo s strokovnjaki pri oblikovanju razvojnih načrtov in pri izpeljavi projektov. Endogeni razvoj je zasnovan na samoupravljanju, avtoorganizaciji, na organskem načrtovanju, kar vse označuje načrtovanje »od spodaj navzgor«, dialoško interakcijo, prevajanje razvojnih ciljev v konkretne aktivnosti in vključevanje različnih strokovnjakov ter metod raziskovanja okolja. Dolci je sodeloval z ekonomisti, agronomi, zdravniki, arhitekti, urbanisti, fotografi ...

Načini, ki jih je uporabljal bodisi zato, da je okolje opozoril na revščino, bodisi pri vzgoji in izobraževanju, izhajajo iz osnovnih načel nenasilja. Uporabljal je različne oblike socialnega pritiska, od gladovne stavke, antistavke (scioperi alla rovescia) do izobraževanja. Izobraževanje je bilo namenjeno družbenim spremembam, v tem je bil podoben južnoameriškemu avtorju Paulu Freireju, in bi ga po tej značilnosti lahko uvrstili med radikalne izobraževalce.

\section{Dialog in avtogenerativnost}

Dolcija kot izobraževalca bi lahko označili z besedami: vprašanje, raziskovanje, iskanje, spraševanje. Zanimalo ga je raziskovanje konteksta, raziskovanje tistega, česar se na prvi pogled ne vidi, iskanje bistva pri učenju, ki je včasih zakrito s tradicijo ali s stereotipi. $\mathrm{Z}$ dialoško metodo je želel učenca spodbuditi, da v sebi odkrije zmožnosti, sposobnosti. Bil je mojster pri oblikovanju intenzivnega čustvenega vzdušja, ki je spod-
Posameznik ima aktivo vlogo pri oblikovanju samega sebe in svojega znanja.

bujalo $\mathrm{v}$ učencih samozaupanje in jim je pomagalo, da so se znebili svojih prepričanj, da ne zmorejo, da niso dovolj dobri in podobno.

Dialoška metoda je način dela, ko skuša učiteljica ali učitelj s spretnim spraševanjem pomagati pri rojstvu novih spoznanj. V besedilih Dolcija je pod majevtično metodo včasih mišljen dialog, včasih pa akcijsko učenje, ko majevtičnost pomeni, da ima skupina za izhodišče nek skupen problem, ki ga želijo razrešiti.

\section{Dolci je potenciale $v$ ljudeh iskals pomočjo dialoške metode.}

Ko rešujejo problem, so pripravljeni poslušati vsa razmišljanja, saj ne gre za prenos že izgotovljenega znanja.

Dolci je postavil dialoške metode in dialoški princip kot pot $v$ drugačne odnose, kot nasprotje dominaciji. Dialog prinaša nov način izobraževanja, izhajajoč iz problemov in člo-

Dolei je uporabljal metode, ki bi jih danes uvrstili $v$ spedagogiko poslušanjak ali pa konstruktivistično pedagogiko, ki izhaja iz teze, da učenje ni transmisija, temveč je graditev, pri kateri sodelujeta posameznikova osebnost in okolje s svojo ponudbo - kakršnakoli že je -, ki jo posameznik predeluje. V srečanju med osebnostjo in okoljem se dogaja učenje. Takšno razmišljanje najdemo danes v delih Gardnerja in Golemana, v delih neopiagetistov, $v$ teoriji kompleksnosti. Bistvo učenja je avtogenerativnost in ne načelo inputa-outputa, ki je prevladovalo v času, ko se je v prakso uvedel behaviorizem kot programirani pouk, kjer učitelj pripravi input, ga preda učencem in pričakuje pri vseh enak output, Učitelj oblikuje kurikulum, kjer se ve, kaj je pravi odgovor. Danilo Dolci pa odkriva skupaj z učenci, zato je vprašanje pogosto pomembnejšse kot odgovor: 
vekovega okolja. Povezuje se s principom avtopoiesis, to je organizacijo rasti, $\mathrm{ki}$ jo opravijo subjekti sami. Zavračal je reproduktivno represivno-pasivizirajočo (šolsko in medijsko) transmisijo in poudarjal samostojno učenje, učenje, povezano $\mathrm{z}$ raziskovanjem, nov odnos med poučevanjem in nčenjem.

\section{Demokracija kot proces}

Za današnje razmišljanje o aktivnem državljanstvu in izobraževanju za aktivno državljanstvo so zanimivi njegovi pogledi na demokracijo, ki jo je želel vpeljati v okolje, v

\section{Dolcijev koncept lokalnega izobra- ževanja najdemo $v$ današnjih načelih trajnostnega razvoja.} katerem je vladal patriarhalni sistem vrednot in mafijski načini medsebojnih reševanj konfliktov.

Izobraževanje, ki ga je pripravljal, je izhajalo iz opredelitve demokracije kot procesa, ker je demokracija povezana $s$ kulturo in ne le $z$ institucijami. Demokracija se začne $v$ prepričanjih in vrednotah ljudi, zato je spodbujal situacije, v katerih bodo ljudje sebe začutili kot vredne in dostojanstvene, procese socialnih sprememb pa je imenoval sprocesi kolektivne rasti $\ll$, ki lahko zrastejo le iz ljudi in ne morejo biti navrženi od zunanjih

Onesnaževanje

uma vladajoči

uporabljajo kot

instrument

ohranitve na

oblasti. institucij, ne morejo se zgoditi na ukaz. Tudi boj proti mafiji zasnuje na večji iniciativi ljudi, prepričan je, da zgolj z vojaško ali policijsko dejavnostjo ne bodo kos mafiji. Potrebno je spreminjati kulturne modele, da bodo ljudje bolj iniciativni in bo dejavnost posameznikov in države zapolnila tisti prostor, ki si ga jemlje mafija.

Demokracija se tesno povezuje $\mathrm{z}$ načelom endogenega razvoja, razvoja, ki ga pripra- vljajo in spodbujajo vse skupine ljudi, ki vključuje tudi marginalizirane skupine. Razvoj s podporo ljudi, brez nasilja, razvoj, ki ni le ekonomski ali tehnični, ampak ima predvsem človeški obraz. Na Siciliji v petdesetih in šestdesetih letih to pomeni, da lahko ljudje kmetujejo, da lahko delajo. V tistih krajih se razvoj razlikuje od enosmerne koncentracije ljudi in kapitala v središčih industrializacije. Razvoj, ki zajame le en sektor ali eno pokrajino, pušča za seboj veliko marginaliziranih skupin ljudi in pokrajin. Dolcijevo razmišljanje se kaže kot aktualno, vzporednice najdemo $v$ načelih trajnostnega razvoja in izobraževanja za aktivno državljanstvo.

\section{Onesnaževanje uma}

Posameznik je sistem, ki je odprt za druge sisteme in za koedukacijo ali medsebojno učenje. Srečuje se z ljudmi in z njimi problematizira obstoječa stanja, ne le sprejema že pripravljenih resnic. Zgolj sprejemanje že izgotovljenih resnic je Dolci imenoval intelektualno kloniranje. $\mathrm{V}$ povezavi s tem je ločeval med močjo in oblastništvom. Tudi v izobraževanju se pojavlja princip gospodovalnosti, četudi je izobraževanje namenjeno osamosvajanju posameznika. Dolci se je zoperstavljal obvladovanju drugega, zoperstavljal se je nadvladi moškega nad ž̀ensko, človeka nad naravo pa tudi nekega korpusa vedenj, ki je uradno priznan kot najpomembnejšs in je navadno vzniknil iz znanja vladajočega sloja ljudi, vladajoče kulture nad znanji, ki izhajajo iz marginalizirane kulture. $\mathrm{V}$ prenosu že izgotovljenih pomenov je videl represijo, ki se kaže $v$ enosmerni poti od vira k uporabniku. Vir je lahko množični medij, šola, lahko je skupina ljudi. Sodobna oblika dominacije je dominacija uma in sodobni dominatorji onesnažujejo ume dominiranih. $\mathrm{Ni}$ govoril le o poluciji narave izven človeka, narave kot okolja človeka, temveč o poluciji uma, ki je veliko bolj prikrita. 


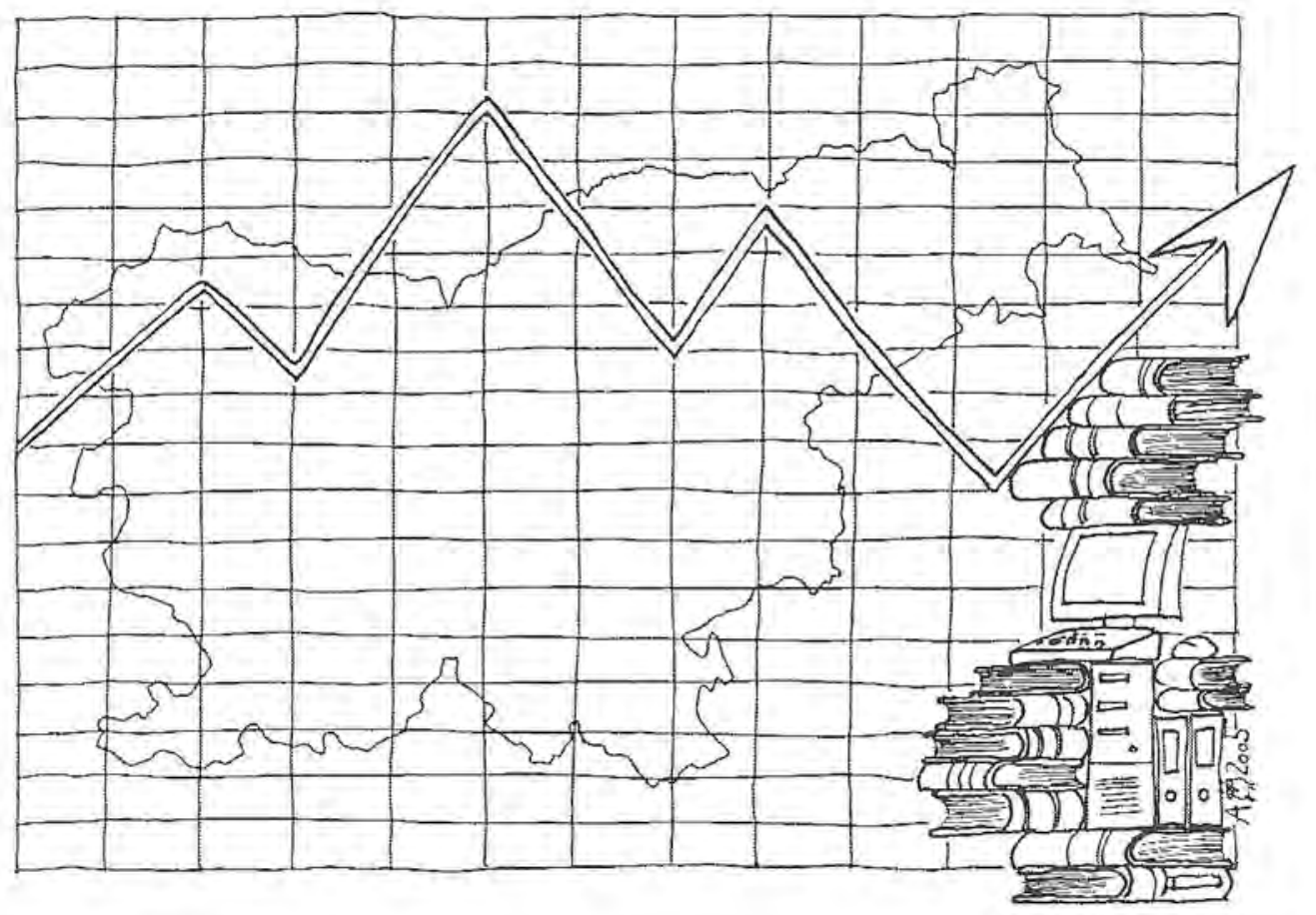

Sodobni ritem, kí prenaša razmerja dominacije, je svobodni trg $v$ povezavi s sofisticirano tehnologijo. Dolci ju je imenoval »letalna in opresivna mešanica «, nastajal je modus vivendi, ki pozna le dominacijo, kot način skupnega bivanja. Dominacija pomeni predvsem gospodovanje, in sicer na tak način, da je gospodar absolutist, ki drži stvari in ljudi v takšnih položajih, ki so njemu ali njej $\mathrm{v}$ interesu, vse je podrejeno njegovi ali njeni avtoritarnosti (Dolci, 1987, str. 72-73). Takšno razmerje lahko poimenujemo patologija moči in demokracija, ki se oblikuje v taki kulturi, je zgolj formalna. Vzgoja in izobraŽevanje naj bi si prizadevala za oblikovanje kulture, ki bi odnose dominacije nadomestila z odnosi sožitja. Je taka želja zgolj utopična?

Virus dominacije se prenaša in klonira ljudi v akterje dominacije, oblikuje industrijo vedenja in znanja, tako da so podani pomeni, ki so za vse ljudi enaki, oblikovano je »uradno znanje«, ki ga določi vladajoči sloj ljudi. Dolci meni, da s takim načinom povzročajo sklerozo razvoja. »Namesto da bi spodbujali učenje, da bi ljudje raziskovali, iskali, gradili svoje znanje, namesto da bi

Dolci (1987, str. 95) je uporabil metaforo virusa za označitev moči in oblastnosti. Tako kot se virus naseli v celici in jo prisili, da deluje po pravilih virusa, tako se je oblastnost naselila v kulturi in ne moremo pričakovati, da bi se ljudje, ki že stoletja živijo v hierarhičnih sistemih, nekega jutra zbudili in si rekli: od danes naprej smo vsi enakopravni in bomo živeli $v$ demokraciji, od današnjega jutra se bomo vedli ustvarjalno, oblikovali bomo sožitje z drugimi ljudmi. Ljudje se morajo šele naučiti, da so avtonomna bitja, da niso le del mase, da je vsaka celica samostojna enota poleg tega, da je del nekega večjega sistema. 
ljudi učili misliti, jim podajamo že izgotovljene misli, ki se jih morajo naučiti, namesto dialoga in komunikacije jim dajemo izdelke in ustvarjamo potrošnike že pripravljenih rezultatov, ki jih ponuja okolje«. (Dolci, 1987, str. 92)

Namesto procesa kloniranja umov, ki pomeni represijo naravnih zmožnosti človeka in inducira nedemokratične in včasih bolne

\section{Ali lahko vzgoja in izobraževanje ustvarita kulturo sožitja?} odnose, se je Dolci zavzemal za interpersonalno komunikacijo. »Virus oblastik se da napasti $\mathrm{z}$ dialoškimi skupinami, je bil prepričan Dolci in zato uvajal dialoške skupine (gruppo maievtico), kjer je bil vsak posameznik odgovoren za svoje učenje in odkrivanje, za razvoj svojih sposobnosti in hkrati odvisen od sebe in od drugih.

Dialoške skupine naj bi bile oblike učenja, s katerimi so se pripravljali na 21 . stoletje. S starimi oblikami učenja, ki so bile značilne za industrijsko dobo 19. in 20. stoletja in so tudi oblikovale industrijsko formo mentis, ljudje niso več sledili razvoju, kaj šele, da bi ga vsi $v$ demokratičnih odnosih oblikovali.

\section{Vladajoči sloj obli- kuje »uradno zna- nje in zavira sa- mostojne procese mišljenja ljudi.}

Če izobraževanje poteka na osnovi vprašanja, ki ga želi učeči se razrešiti, se izobraževanje poveže $\mathrm{z}$ raziskovanjem. Znanje $v$ takem procesu ni več nekaj, kar učeči se ima, ni zaboj podatkov, kovček vedenja, ampak pomeni razvoj osebnih potez. $\mathrm{V}$ tem primeru z znanjem ne povezujemo glagola imeti, temveč glagol biti.

Pri izobraževanju je Dolci poudarjal tiste veščine, ki so potrebne za ustvarjanje znanja: vprašanje, raziskava, hipoteze, raziskovalna metodologija, medosebna komunikacija, pro- instrumenti in hkrati tudi osebnostne poteze, oboje pa se povezuje s kakovostjo učenja. Izobraževanje na ta način začne odgovarjati na temeljna človekova vprašanja, povezana s kakovostjo življenja, s človekovo osebnostno rastjo in s samopotrjevanjem $v$ skupini.

\section{ZAKLJUČKI}

Dolcijevo delo se suče na treh vretenih, in sicer boju proti revščini, posameznikovi aktivni vlogi pri oblikovanju sebe in skupnosti ter endogenem razvoju.

Za boj proti revščini je izbral razne načine nenasilnega protestiranja, osrednjo vlogo pa je namenil izobraževanju vseh prebivalcev, izobraževanju najrevnejših slojev, kajti tandem dominirajočega in dominiranega se ohranja le tedaj, če sistem oba vzdržujeta v ravnotežju. Z vzgojo in izobraževanjem, ki se dogaja formalno, neformalno in priložnostno, je želel spreminjati družbene razmere. V tem pogledu je s svojim razmišljanjem podoben radikalnim pedagogom in še posebno Freireju in njegovi pedagogiki zatiranih.

Pedagoško in andragoško delo, ki se je odvijalo $v$ razvojno-izobraževalnih centrih, na ulicah in plažah, je imelo namen osvobajati posameznika in spodbujati kreativnost. Najbolj izstopajoča metoda je bil dialog in izobraževanje s pomočjo umetnosti, predvsem glasbe, slike. Mangano (2004) ga je označil kot izjemnega človeka, ki se giblje proti toku. Hotel je pomagati ljudem z roba in je pri tem razvil svojo metodo in filozofijo vzgoje, $\mathrm{ki}$ sloni na načelu, da je potrebno otrokom in odraslim pomagati raziskovati in oblikovati kulturo, ne pa vsiljevati repeticijo in reprodukcijo tiste kulture, ki so jo oblikovali drugi.

Svojega opusa Dolci ni zasnoval na papirju, marveč med ljudmi, v boju z mafijo in zaostalostjo neke pokrajine, ki je vkleščila svoje 
prebivalce na robu razvoja. Zoperstavil se je dominantnosti in dominiranju bodisi človeka nad človekom ali človeka nad naravo. Izobraževanje naj bo v službi človeka, naj mu pomaga reševati probleme $v$ okolju in soočati se s svetovnimi problemi, kot so kriminal, begunci, odvisnost od mamil, neravnotežje med severom in jugom in tudi poskusi, da zahodna kultura preplavi vse ostale.

\section{Dolci - svetnik 20. stoletja?}

O Dolciju razmišljajo različni ljudje različno, nekateri menijo, da je bil prevarant, drugi pa so navdušeni nad njegovim delom. Aldous Huxley je v uvodu v Dolcijevo knjigo To Feed the Hungry zapisal, da je Dolci moderni sv. Frančišek, ki združuje znanje in dobrodelnost ('knowledge and charity'). Znanje brez dobrodelnosti lahko postane nečloveško in dobrodelnost brez znanja nima moči. Dolci je bil predan ljudem. Ko ga je nekoč prijatelj vprašal: »Kako to, da ne uporabljaš več besede bog? , mu je odgovoril: »Ko sem ugotovil, da beseda bog prinaša med ljudi več razdora kot pomiritve, sem jo opustil. Verjamem $v$ ustvarjalnost in ustvarjalnost se zgodi z božjo voljo toda brez fatalizma, prosim. $«$

Skozi celoten tekst ugotavljamo podobnosti med Freirejem in Dolcijem in ob koncu se lahko vprašamo, kakšna je vrednost dela radikalnih pedagogov in andragogov za sodobnost.

\section{V čem je vrednost Dolcijevega dela za sodobnike?}

Sodobni čas je čas disutopije (McLaren, 1999, XXV). To je sodobni projekt, ki slavi konec socialnih sanj. To ni indiferentnost, to je aktivni proces, ki želi nadzorovati vse razlike med moškimi in ženskami, med rasami, verami, slavi individualno samodoločanje in samorealizacijo, za vse je odgovoren posameznik, ki pozablja na drugega in na skupnost. Rezultat tega je socialna shizofrenija. In ker razlike ne morejo biti izničene $s$ političnim in filozofskim hotenjem, se razvijejo ugodna tla za disutopijo, ki načrtno dekonstruira, zanika, pozablja. Dolcijevo delo je izziv za sodobni projekt disutopije, njegova pedagogika (Dolci ni uporabljal izraza andragogika) je eden od napovednikov kritike globalnega izkoriščanja in zatiranja, ni sledilka in izvrševalka navodil kapitala, temveč razvija solidarnost in skupno življenje, sloneče na dialogu.

\section{LITERATURA IN VIRI}

Dolci, D. (1987). La creatura e il virus del dominio, Latina: L'Argonauta.

Dolci, D. (1996). La struttura maieutica e l'evolverei. Firenze: Nuova Italia.

Dolci, D. (1963, 1974). Racconti siciliani. Torino: Einaudi.

Freire, P. (1971). Pedagogy of the oppresed. New York: Herder and Herder.

Gardner, H. (1996). Educare al comprendere. Milano. Feltrinelli.

Huxley, A. (1959). Introduction. To feed the hungry. London: McGibbon \& Kee.

Mazzoleni, C. Nota biografica su Danilo Dolci (http://danilo1970.interfree.it/notadolci.html. 19.12. 2004).

Mangano, A. Danilo Dolci. Ricordi e riflessioni (http://danilol970.interfree.it/ricordi_riflessioni.html, 23, 12, 2004).

Mangano, A. Educazione e dominio in Danilo Dolci (http://danilo1970.interfree it/potere.html, 23.12. 2004).

Mangano, A. Educazione e istruzione nel pensiero e nell'opere di Danilo Dolci. (http://danilo1970. interfree.it/educazione.html, 23.12. 2004).

Mangano, A. (1992). Danilo Dolci educatore, Firenze: Edizioni Cultura della pace.

McGivney, V. (1999). Informal learning in the 
community. Leicester: NIACE.

McLaren, P. (2000). Che Guevara, Paulo Freire, and the pedagogy of revolution. Lanham, Boulder, New York, Oxford: Rowman \& Littlefield Publ,

McNeish, J. (1965). Fire under the ashes. London: Hodder and Stoughton.

Novara, D. La pedagogia maieutica di Danilo Dolci (http://danilo1970.interfree.it/novara.html, 19. 12. 2004).

Novara, D. (2002). L'ascolto si impara. Torino: Edizioni Gruppo Abele.

Skrinjar, P. (2004). Danilo Dolci: pedagog, poet, mirovnik. Primorska srečanja, XXVIII/279-80, str. 33-39.

Spagnoletti, G. (1977), Conversazioni con Danilo Dolci. Milano: Mondadori.

Villari, L. Addio al Ghandi di Scilia (http://danilo1970.interfree.it/gan,html, 19, 12, 2004).

Walker, F. Danilo Dolci

(http://danilo1970.interfree.it/wal.html, 19. 12. 2004).

Welch, J. Danilo Dolci

(http://www.uwgb.edu/galta/333/dolci.htm, 23. 12. 2004).

www.danilodolci.net

www.danilodolci.toscana.it

Pogovor s Pavlom Skrinjarjem (januar 2005).

Pogovor s Cirilom Zlobcem (februar 2005). 